\title{
EKONOMI DALAM PERSPEKTIF ISLAM
}

\author{
Moch. Khoirul Anwar*
}

\begin{abstract}
A bstract: Economic misbehavior would certainly impact on the economic performance of a society. As a religion, Islam realizes this and knows that economic misconduct must be diagnosed. Islam encourages that in order for the economic sustenance to be materialized human and natural resources must be explored to the maximum. Economic sustenance is the goal for any country. And Islam supports a policy toward that sustenance. The fact that Islam loves a strong society means that this religion supports a sound economic policy that would work toward the realization of a well-off society. The Qur'an states that one must explore the world and seek the providence of God. To "explore the world" is a divine command. The logic behind this command is that, first, one must work to earn fortune so that his worldly needs can be met, and second, he must develop a system so that he may earn the fortune both in legitimate and progressive way. In Islam, working is a form of worship. It is therefore rewarding. But Islam also encourages that we develop a comprehensive, holistic, realistic, just, responsible, and balanced economic system so that our economic sustenance may be realized. Islam believes that the goal of any economic sustenance is the materialization of social and economic welfare. All members of society irrespective of their race, religion and color must benefit from that sustenance.
\end{abstract}

Keywords: economic sustenance, the economy of the ummah

\section{Pendahuluan}

Satu hal yang tidak bisa dipungkiri, bahwa sekarang umat Islam masih banyak yang berada di bawah garis kemiskinan. Artinya masih banyak di antara mereka yang tingkat standar hidupnya rendah. Standar kehidupan yang rendah ini secara langsung akan memberikan pengaruh yang besar terhadap kesehatan, moral dan rasa harga diri mereka. Di samping itu, ketidakberdayaan ekonomi merupakan bahaya besar terhadap stabilitas ketentraman, kesejahteraan dan keamanan masyarakat, bahkan terhadap keimanan seseorang. Padahal kondisi yang demikian justru bertentangan dengan ajaran Islam yang menuntut umatnya untuk berdaya di bidang ekonomi.

Islam adalah agama yang universal. Ajaran-ajaran Islam mengatur dan membimbing semua aspek kehidupan manusia, baik yang berdimensi vertikal (habl min al-Allah) maupun yang berdimensi horizontal (habl min al-nas). AI-Q ur'an sebagai sumber utama ajaran Islam yang di dalamnya berisi aqidah, shari'ah, sejarah dan etika (moral), mengatur tingkah laku dan tata cara kehidupan manusia, baik sebagai makhluk individu maupun sebagai makhluk sosial. U niversalitas ini tampak jelas terutama dalam aspek muamalah yang sangat luas medan geraknya, bersifat relatif dan fleksibel sesuai dengan situasi, kondisi dan domisili. Ini berbeda secara diametral dengan aspek ibadah (formal) yang bersifat absolut-permanen-konstan dan tak berubah-ubah sebagaimana yang telah diajarkan Rasulullah.

Kaitan antara aspek ibadah formal (dalam arti sempit) dan mua'amalah secara sangat menarik diilustrasikan dalam surat al-J umu'ah ayat $9-10$ berikut: 
“Hai orang-orang yang beriman, apabila diseru untuk melakukan sembahyang pada hari jum'at, maka bersegeralah kamu kepada mengingat Allah dan tinggalkanlah aktifitas ekonomi. Yang demikian itu lebih baik bagimu jika kamu mengetahui.

"A pabila telah ditunaikan sembahyang, maka bertebaranlah kamu di muka bumi dan carilah karunia (kelebihan) Allah banyak-banyak supaya kamu beruntung". ${ }^{1}$

Ayat di atas berisi ajaran normatif yang indah sekali mengenai bagaimana seharusnya seorang Muslim hidup di muka bumi dalam kaitannya dengan pelaksanaan ibadah dan mu'amalahnya. Pertama ditegaskan bahwa ibadah (shalat J um'at) harus segera ditunaikan ketika waktunya telah tiba, dan semua aktifitas ekonomi harus ditinggalkan, begitu ibadah selesai, manusia diperintahkan untuk segera bermu'amalah kembali (mencari rizki). Ini menunjukkan bahwa aktifitas ekonomi diperintahkan oleh ajaran Islam, sebagaimana diperintahkannya aktifitas ibadah. Keseimbangan (equilibrium) antara ibadah dan mu'amalah inilah yang selalu ditekankan oleh Islam.

al-Qur'an memang tidak merinci dalam satuan konsep ekonomi teoritis praktis, tetapi senantiasa mendorong kepada umatnya untuk sejahtera di bidang ekonomi. ${ }^{2}$ Dalam al-Q ur'an terdapat terma komersial sebanyak duapuluh macam terminologi, yang diulang sebanyak 370 kali. ${ }^{3} \mathrm{H}$ al ini menunjukkan sebuah manifestasi adanya sebuah spirit yang bersifat komersial dalam al-Q ur'an. Dengan demikian setiap Muslim sebagai individu mempunyai tanggung jawab yang sama untuk membentuk dan menghasilkan kerja yang produktif. Tanggung jawab semacam ini tidak hanya berdimensi kemanusiaan saja, akan tetapi juga berdimensi ke-ilahi-an, artinya dalam mempertanggungjawabkan semua aktifitas produksi (pemberdayaan ekonomi), manusia dituntut bertanggungjawab di hadapan sesama manusia, dan di hadapan Tuhan tatkala di akherat kelak ${ }^{4}$.

\section{Problem perekonomian ${ }^{5}$ dalam negara berkembang}

Bagaimanapun juga, antara ekonomi dengan politik tidaklah bisa dipisahkan, terutama jika sudah menyangkut partisipasi dalam mengembangkan masyarakat, karena prinsip partisipasi ini tentunya berkaitan dengan ideologi ekonomi suatu masyarakat. Sehingga dalam perkembangannya muncul beberapa pandangan mengenai partisipasi tersebut. Pandangan pertama melahirkan pendapat tentang perlunya terlebih dahulu dikembangkannya demokrasi politik, sehingga masyarakat akan memperoleh kesempatan yang luas untuk mengembangkan kreasi dan inovasinya dalam kegiatan ekonomi, dan hal ini juga terkait dengan demokrasi

\footnotetext{
${ }^{1}$ al-Qur'an, 62 (al-J umu'ah) : 9-10.

${ }^{2}$ Salah satu contohnya adalah yang terdapat dalam al-Q ur'an 4: 9. Kaitannya dengan ini, lihat: Alwi Shihab, Islam Inklusif; Menuju Sikap Terbuka dalam Beragama (Bandung: Mizan, 1997), 172-173.

${ }_{3}^{3}$ Perhitungan ini sebagaimana yang dikutip oleh Mustaq Ahmad dari disertasi CC. Torrey, The Commercial-Theological Terms in the Koran. Lihat Mustaq Ahmad, Business Ethics in Islam (Pakistan: The International Institute of Islamic Thought, 1999), 16.

${ }^{4}$ M. Abdul Manan, Islamic Economic, Theory and Practice (New Delhi: Idarat-i Delhi, 1980), 60.

${ }^{5}$ Secara ilmu ekonomi, Problem ekonomi ini timbul sebagai akibat adanya ketidak seimbangan antara keinginan manusia untuk mendapatkan barang dan jasa dengan kemampuan faktor-faktor produksi dalam menghasilkan barang dan jasa untuk memenuhi keinginan tersebut. Lihat Sadono Sukirno, Pengatar Teori M ikro Ekonomi (J akarta: Rajawali Pers, 1994), 52.
} 
ekonomi yang berarti kebebasan dalam berusaha. Pandangan kedua melahirkan pendapat bahwa yang penting adalah pertumbuhan ekonomi terlebih dahulu, walaupun dengan mengorbankan demokrasi politik untuk sementara waktu.

Di negara berkembang, termasuk Indonesia, ternyata dalam prakteknya lebih mengarah pada pandangan yang kedua. Hal ini terjadi karena ada pandangan bahwa demokrasi politik membutuhkan beberapa syarat yang berkaitan dengan ekonomi, di antaranya: pertama, tingkat pendapatan masyarakat. Dengan pendapatan yang besar, negara atau masyarakat bisa mengeluarkan biaya dalam usaha peningkatkan mutu pendidikannya, sehingga bisa memperluas partisipan demokrasi yang sehat. Dengan kata lain, ketika seseorang sudah bisa memenuhi kebutuhan pokoknya, maka dia akan berusaha untuk meningkatkan kualitas hidupnya dengan melakukan partisipasi dalam kehidupan politik. Kedua, bahwa bantuan dari pemerintah yang selama ini diberikan pada masyarakatjustru malah menciptakan situasi ketergantungan. Motivasi masyarakat akan tergantung oleh rangsangan yang berupa materiil, sehingga partisipasi masyarakat hanya terjadi pada sektor-sektor yang mendapat bantuan dari pemerintah. Ketiga, perlunya lembaga-lembaga yang bisa merangsang peran serta masyarakat sendiri. Lembagalembaga ini bertujuan untuk menyediakan wadah partisipasi bagi masyarakat, yaitu wadah yang lebih bisa mempersatukan dan bisa mencegah terjadinya konflik, seperti KUD, PKK, dan lain sebagainya. Lembaga-lembaga ini harus disetting sedemikian rupa sehingga masyarakat benar-benar merasa memilikinya dan ikut bertanggungjawab mengelola dan mengembangkannya. ${ }^{6}$

Dalam rangka usaha untuk meningkatkan pertumbuhan ekonomi itulah, sehingga pembangunan ekonomi ${ }^{7}$ dalam suatu negara berkembang sangatlah dibutuhkan. Di negaranegara berkembang bisa dijalankan tiga pola pembangunan, yang pada garis besarnya sebagai berikut:

Pertama, pola pembangunan yang menitik beratkan kenaikan produksi secara cepat untuk mendorong pertumbuhan ekonomi semaksimal mungkin, sehingga tercapai tingkat GNP yang besar tanpa mempersoalkan terlaksananya redistribusi pendapatan. Kenaikan produksi secara cepat tersebut bisa ditempuh dengan investasi sebanyak mungkin, baik domestik maupun asing. Kedua, pola pembangunan yang mengejar pola pertumbuhan ekonomi, yaitu dengan melalui usaha menaikkan produksi secara cepat, akan tetapi sejak semula mengidam-idamkan adanya pembagian pendapatan yang merata. Ketiga, pola pembangunan yang menghendaki pertumbuhan ekonomi semaksimal mungkin melalui usaha menaikkan produksi, akan tetapi usaha itu harus dibarengi dengan penanganan langsung masalah-masalah yang terjadi di negara

\footnotetext{
${ }^{6}$ M. Dawam Rahardjo, Perekonomian Indonesia; Pertumbuhan dan Krisis (J akarta: LP3ES, 1997), 196-199.

${ }^{7}$ Istilah pertumbuhan ekonomi berbeda dengan istilah pembangunan ekonomi. Pertumbuhan ekonomi lebih menekankan pada proses peningkatan produksi barang dan jasa dalam kegiatan ekonomi masyarakat. Sedangkan pembangunan ekonomi mengandung arti yang lebih luas dan mencakup perubahan pada tata susunan ekonomi masyarakat secara menyeluruh. Pembangunan merupakan proses transformasi yang dalam perjalanan waktu ditandai oleh perubahan struktural, yaitu perubahan pada landasan kegiatan ekonomi maupun pada kerangka susunan ekonomi masyarakat yang bersangkutan. Lihat: Sumitro Djohohadikusumo, Perkembangan pemikiran ekonomi; Dasar Teori Ekonomi Pertumbuhan dan Ekonomi Pembangunan (J akarta: LP3ES, 1994), xi.
} 
berkembang tersebut. $^{8}$

Bagaimanapun juga usaha yang dilakukan oleh negara-negara berkembang dalam memperbaiki tatanan ekonomi mereka, di sana masih juga bermunculan problem-problem langganan yang dihadapi oleh negara berkembang, di antaranya kesenjangan dan pengangguran. Hal itu bisa jadi disebabkan karena negara-negara berkembang pada umumnya masih terus mengalami pertambahan penduduk. Dengan sendirinya, kebutuhan masyarakat menjadi semakin meningkat, terutama mengenai serangkaian keperluan hidup yang sifatnya sangat mendasar, yaitu pangan, sandang, pemukiman, pendidikan dan kesehatan. Di zaman dulu mungkin pendidikan dan kesehatan dikelompokkan pada kebutuhan sosial ${ }^{9}$, tetapi dalam pembangunan ekonomi negara berkembang, kedua jenis kebutuhan tersebut bisa dianggap prioritas ekonomi yang utama, karena peningkatan mutu pendidikan dan pelayanan kesehatan sangat mempengaruhi kualitas sumber daya manusia.

Masalah pangan sebenarnya tidak hanya dilihat secara kuantitatif saja, yaitu jumlahnya yang tersedia untuk konsumsi rakyat, tetapi lebih dari itu, masalah kualitas atau mutu pangan dan aspek gizi juga harus diperhatikan terutama yang menyangkut keseimbangan dalam hal karbohidrat, vitamin dan protein ${ }^{10}$. Begitu pula dengan masalah pemukiman yang sekarang menjadi masalah yang sangat peka, karena memang jumlah penduduk yang semakin bertambah ${ }^{11}$. Dalam hal ini bukan hanya bagaimana caranya menyediakan rumah murah bagi penduduk, tetapi secara arti luas juga mencakup penyediaan tanah dan sumber air serta pelestariannnya. Di antara kebutuhan pokok rakyat yang tidak kalah pentingnya juga adalah masalah peningkatan kualitas manusia sebagai sumber daya produksi yang harus diselenggarakan berdasarkan pendidikan untuk meningkatkan ketrampilan teknis, keahlian profesional dan kecerdasan akademis. ${ }^{12}$

Secara logika jelaslah apabila sebagian rakyat masih kekurangan sebagian komponenkomponen dasar dalam hidupnya (sandang, pangan, pemukiman, pendidikan dan kesehatan), maka kehidupan rata-rata mereka akan tetap dalam pola dan tingkat yang rendah dan tertekan, sehingga mengharuskan pengadaan kebutuhan dasar yang besar. Pada akhirnya, situasi yang demikian akan mengharuskan penciptaan lapangan kerja yang bersifat produktif, karena peningkatan produksi barang dan jasa yang tanpa diimbangi penciptaan lapangan kerja produktif

\footnotetext{
${ }^{8}$ Wilopo, "Pemerataan Bukan Rata-Rata", dalam Sri Edi Swasono (ed), Sistem Ekonomi dan Demokrasi Ekonomi (J akarta: UI-Press, 1987), 241-243.

${ }^{9}$ Dalam kaca mata Islam, al-Zuhaili menformulasikan kebutuhan pokok dalam kehidupan manusia adalah: makanan, pakaian, minuman dan tempat tinggal. Lihat: Wahbah al-Zuhaili, Tafsir al-M unir fi al-Aqidah wa al-Shari'ah wa alManhaj (Beirut: Daral-Fikr, 1991),296.

${ }^{10}$ Contoh kasus tentang masalah ini adalah terjadinya penyakit busung lapar yang pernah melanda Indonesia. Itu terjadi disebabkan kurangnya persediaan pangan, baik secara kuantitas maupun kualitas. $\mathrm{H}$ al ini adalah sebagian kecil dari dampak problem pangan yang terjadi di negara berkembang.

${ }^{11}$ Belum lagi ditambah dengan adanya beberapa bencana alam yang akhir-akhir ini terjadi di Indonesia seperti gelombang Tsunami, tanah longsor, lumpur Lapindo dan lain sebagainya yang menghancurkan banyak pemukiman penduduk. Hal ini sedikit banyak akan menyita perhatian pemerintah untuk segera menyediakan pemukiman bagi mereka.

${ }^{12}$ Sumitro Djohohadikusumo, Perkembangan Pemikiran Ekonomi; Dasar Teori Ekonomi Pertumbuhan dan Ekonomi Pembangunan (J akarta: LP3ES, 1994), 62.
} 
justru akan cenderung mempertajam ketimpangan dalam hal pembagian pendapatan dan kesenjangan yang terjadi di masyarakat.

Di daerah pedesaan yang masih mengandalkan mata pencarian bertani akan muncul problem tersendiri, karena dengan nisbah jumlah penduduk dan angkatan kerja yang semakin meningkat dibandingkan dengan luas tanah yang tersedia, maka pemilikan tanah akan semakin kecil dan terpencar-pencar ${ }^{13}$. Akibatnya akan terjadi apa yang kita kenal dengan pengangguran terselubung di daerah pedesaan. Sehingga yang dilakukan oleh sebagian orang pedesaan adalah berbondong-bondong mencari kerja di perkotaan, yang hal ini akan mengakibatkan masalah urbanisasi, karena sebenarnya banyak tenaga kerja di perkotaan yang tidak sepenuhnya produktif sehingga tidak bisa mencukupi kebutuhan hidupnya.

Problem terpenting yang dihadapi negara berkembang adalah masalah kemiskinan. Secara singkat, kemiskinan dapat didefinisikan sebagai suatu standar tingkat hidup yang rendah, yaitu adanya suatu tingkat kekurangan materi pada sejumlah orang dibandingkan dengan standar kehidupan pada umumnya yang berlaku pada masyarakat yang bersangkutan. Standar kehidupan yang rendah ini secara langsung akan memberikan pengaruh yang besar terhadap kesehatan, moral dan rasa harga diri mereka. Pemahaman pengertian kemiskinan ini dalam ilmu sosial dapat dilakukan dengan menggunakan tolak ukur. Tolak ukur yang dipakai adalah berdasarkan tingkat pendapatan per waktu kerja. ${ }^{14}$

\section{Pemberdayaan Ekonomi Umat}

Keberdayaan ekonomi masyarakat merupakan kondisi yang diharapkan, yang mana titik beratnya adalah tercapainya kesejahteraan manusia. ${ }^{15}$ Aspek ekonomi ini sangat penting, bahkan dalam uslyl bal-fiqh ia termasuk salah satu dari lima aspek yang dilindungi, yang terkenal dengan al-umupal-dłrupiyah li al-nas yaitu: agama, jiwa, akal, keturunan dan harta. ${ }^{16} \mathrm{Hal}$ ini sejalan dengan tujuan sharisah yaitu hikmah dan kemaslahatan manusia di dunia dan di akhirat. Kemaslahatan ini terletak pada keadilan, rahmat, kebahagiaan dan kebijaksanaan. Tindakan apapun yang bertentangan dengan keadilan, dan merubah rahmat menjadi kesulitan, kesejahteraan menjadi kesengsaraan dan hikmah menjadi kebodohan, maka semua itu tidaklah berhubungan dengan sharisah Islam. ${ }^{17}$

Di sisi lain, ketidakberdayaan ekonomi merupakan bahaya besar terhadap stabilitas ketentraman, kesejahteraan dan keamanan masyarakat, bahkan terhadap keimanan seseorang. A palagi ketidakberdayaan ini disebabkan karena ketidakadilan distribusi antara mereka, terjadinya perampasan hak dari sebagian masyarakat kepada yang lain, pengeksploitasian atas komunitas yang tak berdaya, maka pada saat seperti itu sangat memudahkan timbulnya

\footnotetext{
${ }^{13} \mathrm{~A}$ palagi ditambah dengan kecenderungan orang-orang perkotaan (baca: konglomerat) yang berlomba-lomba membeli tanah di pedesaan yang kemudian tidak diperuntukkan untuk lahan produktif, maka hal ini tentunya akan memperkecil pemilikan tanah oleh orang desa itu sendiri.

${ }^{14}$ Parsudi Suparlan, Kemiskinan di Perkotaan; Bacaan untuk Antropologi Perkotaan ( akarta: Yayasan O bor Indonesia, 1995), xi.

${ }^{15}$ al-Qur'an, 2 (al-Baqarah) : 21.

${ }^{16}$ Wahbah al-Zuhaili, Usullaal-Figh al-Islami łDamaskus: Dasal-Fikr, 1986), 102.

${ }^{17}$ Ibn al-Q ayyim al-J awziyah, A'lam al-M uwaqi' in, J uz III (B eirut: Dasal-Kutub al-'Ilmiłah,1993), 11.
} 
instabilitas dalam kehidupan di masyarakat, yang pada akhirnya akan meruntuhkan sendi solidaritas dan kasih sayang di masyarakat. Memang dalam al-Qur'an terdapat term kelas penindas (Mustakbirin) dan kelas tertindas (Mustad'afin) yang terdapat konflik di antara mereka ${ }^{18}$, namun ini bukan dalam arti Islam melegalkan konflik sosial. Dalam hal ini agama Islam memberikan tata aturan bagi masing-masing kelas tersebut, yang berupa kewajiban dan hak masing-masing. Dengan kata lain, mereka yang hidup di tengah-tengah masyarakat tersebut tidak boleh berlepas tangan, karena mereka punya tanggung jawab masing-masing.

Perilaku manusia yang bisa mengakibatkan ketidakberdayaan di bidang ekonomi sangat bertentangan dengan semangat kerja yang dianjurkan oleh Islam. Islam menganjurkan agar manusia memanfaatkan potensi dirinya (Sumber Daya Manusia) dan potensi alam (Sumber Daya Alam) dalam bekerja. Pemanfaatan potensi diri semaksimal mungkin dalam bekerja akan membawa kepada keberdayaan ekonomi manusia sehingga mereka menjadi kelompok yang kuat (berdaya), kelompok yang disukai oleh Allah. ${ }^{19}$

Agama Kristen juga menganjurkan adanya kerja keras sebagai syarat untuk memperoleh kemajuan, yang berarti pembangunan harus mendapat perhatian utama dari berbagai kalangan. Inilah ajaran Santo Thomas Aquinas dan Calvin bahwa bekerja adalah sekaligus keharusan dan panggilan bagi umat manusia ${ }^{20}$. Amal dan ibadah harus selalu dikaitkan dalam kegiatan manusia sehari-hari, tidak peduli apakah dia orang Islam, Kristen ataupun agama yang lain.

Di samping itu, manusia merupakan agen dan obyek dari pembangunan. Pernyataan ini mempunyai konsekwensi bahwa sumber daya manusia merupakan salah satu faktor yang sangat penting dalam pembangunan di segala bidang, termasuk pembangunan ekonomi. Hal ini mengingat bahwa manusia adalah penggerak dalam pembangunan yang mengantisipasi masalah, membuat perencanaan, mempertimbangkan sistem nilai agama dan masyarakat, menggali sumber alam, mengakumulasi dana, membangun organisasi sosial, ekonomi dan politik serta meletakkan semuanya dalam satu wadah pembangunan.

Bertolak dari pentingnya keberdayaan ekonomi masyarakat itulah sehingga secara struktural, pemerintah berkewajiban untuk memperdayakan ekonomi rakyatnya, dengan tanpa melihatapakah rakyatnya itu termasuk kelas atas atau kelas bawah. Berdaya tidaknya masyarakat, pada akhirnya pemerintah juga akan mendapatkan dampak positifnya, karena keberdayaan masyarakat menjadi sumber apa yang dikenal dengan ketahanan nasional. Memberdayakan masyarakat berarti upaya untuk meningkatkan harkat dan martabat lapisan masyarakat yang dalam kondisi tidak mampu melepaskan diri dari belenggu kemiskinan dan keterbelakangan.

Kata pemberdayaan (empowerment) memang mudah diucapkan, tetapi sebenarnya yang harus diperhatikan dalam hal pemberdayaan ini adalah pemahaman yang mendalam tentang pengertiannya dan implikasinya pada sikap dan tindakan nyata dalam pembangunan masyarakat. Pemberdayan adalah upaya untuk membangun daya masyarakat dengan mendorong, memotivasi, dan membangkitkan kesadaran akan potensi yang dimiliki serta berupaya untuk

\footnotetext{
${ }^{18}$ Syed Nawab Haider Naqvi, Islam; Economic And Society (London And New York: Kegan Paul International, 1994), 74.

${ }^{19}$ Al-Nawawi, Sahih Muslim bi Sarh Imam al-Nawawi,YVIII, (Beirut: Daral-Fikr, 1981), 215.

${ }^{20}$ Taufik A bdullah, Agama, Etos Kerja dan Perkembangan Ekonomi (J akarta : LP3ES, 1979), 92.
} 
mengembangkannya. Keberdayaan masyarakat adalah suatu hal yang paling mendasar bagi masyarakat untuk bertahan dan mengembangkan diri untuk mencapai kemajuan. ${ }^{21}$

Dalam usaha pemberdayaan ekonomi ini tentunya yang pertama kali dilihat adalah bagaimana pemberdayaan ekonomi dalam lingkup yang lebih kecil, yaitu keluarga. $\mathrm{Hal}$ ini sesuai dengan Firman Allah dalam al-Qur'an surat al-Nisabayat 9 :

“Dan hendaklah takut pada Allah orang-orang yang sekiranya meninggalkan anak-anak yang lemah di belakang mereka yang mereka khawatir terhadap (kesejahteraan) mereka, maka hendaklah mereka bertaqwa kepada Allah dan hendaklah mereka mengucapkan perkataan yang benar".22

Bentuk dari pemberdayaan ini bisa dilakukan dengan pengembangan kewirausahaan yang dilakukan oleh sebuah keluarga, sehingga akan tercipta suatu bentuk kemandirian usaha ekonomi produktif. Pada akhirnya akan terwujud suatu keluarga yang lebih dan semakin sejahtera serta mandiri. Di antara indikasi dari keluarga sejahtera ini adalah adanya kemampuan fungsional keluarga dalam memenuhi kebutuhan dasar sehingga mampu memberi kontribusi terhadap kebutuhan kehidupan masyarakat.

Akan tetapi, pengembangan kewirausahaan keluarga tersebut tentunya membutuhkan suatu jaminan struktural, dalam hal ini pemerintah, untuk mendorong dan memperlancar usaha tersebut. Kegiatan ekonomi produktif khususnya yang dilakukan masyarakat bawah tanpa jaminan struktural, bisa diibaratkan melepas anak kecil di tengah-tengah lalu lintas ibu kota. Ini menunjukkan betapa pentingnya peran pemerintah dalam pengembangan usaha produktif tersebut. Kebijakan yang demikianpun masih memerlukan suatu kebijakan perlindungan ekonomi yang tidak hanya diperlukan oleh perusahaan besar ekonomi modern, tetapi justru merupakan suatu hal yang sangat penting dan fungsional bagi masyarakat bawah.

Paradigma pembangunan ekonomi dengan mempercayakan kekuatan ekonomi negara hanya pada lembaga perekonomian yang besar justru akan memunculkan lemahnya daya beli dan produktifitas ekonomi basis utama kekuatan negara itu sendiri. Lembaga perekonomian besar dan modern memang memberikan sumbangan yang besar pula bagi devisa negara, tetapi kalau tanpa diimbangi kekuatan ekonomi produktif rakyat banyak, maka justru besarnya cadangan devisa negara merupakan kekuatan semu belaka, karena pada akhirnya devisa negara itupun harus menanggung beban ekonomi mayoritas rakyat sebagai tanggung jawab kenegaraan. ${ }^{23}$

Di negara Indonesia, di antara konsep pemberdayaan yang pernah diterapkan adalah pelaksanaan program nasional penanggulangan kemiskinan berdasar inpres yang kemudian lebih dikenal dengan program IDT. Selain IDT, program pemberdayaan ekonomi yang telah dilakukan adalah J PS (J aring pengaman Sosial). Program ini muncul karena dampak krisis moneter dan lanjutan krisis ekonomi pada tahun 1998. Selanjutnya program penanggulangan kemiskinan yang sampai sekarang masih berjalan adalah BLT (Bantuan Tunai Langsung) yang diberikan kepada masyarakat miskin sebagai kompensasi kenaikan BBM. Secara konsep,

${ }^{21}$ Mubyarto, Membangun Sistem Ekonomi (Yogyakarta: BPFE, 2000), 263.

22 al-Qur'an, 4 (al-Nisas): 9.

${ }^{23}$ Abdul Munir Mulkhan, "Pemberdayaan Budaya Ekonomi Domestik", dalam Kumala Hadi (ed), Agenda Aksi Liberalisasi Ekonomi dan Politik di Indonesia (Yogyakarta: PT. Tiara Wacana, 1997), 354. 
memang program-program tersebut sangatlah baik, tetapi dalam tatanan praktek program ini banyak menimbulkan pro kontra, terutama dari pejabat yang menganggap program ini menambah beban pekerjaan yang berat bagi mereka. Apalagi ada kekhawatiran dengan adanya program BLT bisa membuat masyarakat malas bekerja, dan hanya mengharapkan pemberian dari pihak lain.

Dalam pandangan ekonomi Islam, program pemberdayaan ekonomi umat sangatlah cocok dengan ajaran Islam, karena tujuan dari ekonomi Islam adalah menciptakan kehidupan manusia yang aman dan sejahtera. Manusia di sini berarti semua golongan manusia, baik yang sehat atau yang sakit, kuat atau lemah, susah atau senang, serta manusia sebagai individu atau sebagai masyarakat ${ }^{24}$. Islam sendiri mempunyai perhatian yang serius tentang keadilan sosial dan ekonomi, karena Islam memandang bahwa martabat kemanusiaan adalah suatu hal yang essensial, sehingga setiap manusia berperan untuk mendapatkan kebahagiaan hidupnya. Islam juga memberikan kesadaran yang mendalam bagi kita bahwa kemakmuran ekonomi tidak akan kita dapatkan tanpa adanya hubungan sosial yang harmonis ${ }^{25}$. Hal ini terbukti apabila dalam suatu negara terjadi adanya kesenjangan sosial yang tajam, maka perekonomian negara tersebutpun akan berjalan dengan tersendat-sendat.

Islam memang mengajarkan pertumbuhan dan perkembangan ekonomi dalam sebuah negara ${ }^{26}$, bahkan bukan hanya pembangunan dan pertumbuhan di bidang materiil saja, tapi segi spiritual dan moralpun menempati kedudukan yang sangat penting ${ }^{27}$. J adi, konsep Islam tentang pembangunan dan pertumbuhan ekonomi lebih luas dari pada konsep ekonomi sekuler. Walaupun dasar pembangunan ekonomi islami adalah multidimensional yang mempunyai dimensi-dimensi moral, sosial, politik dan ekonomi, namun sejak awal, pembangunan moral dan spiritual sudah terintegrasi dalam pembangunan ekonominya. Selain itu, dipandang dari segi material, penekanan pada kenaikan pendapatan perkapita dan pertumbuhan yang cepat dan terus menerus dalam suatu masa tertentu, belum tentu menjamin terciptanya kondisi islami untuk pertumbuhan ekonomi, karena hasil pendapatan itu juga belum tentu memberikan solusi luasnya kesenjangan dalam pembagian pendapatan. Sehingga Islam melihat bahwa pertumbuhan dan pembangunan ekonomi lebih dari sekedar persoalan materi dan memiliki tujuan yang lebih universal dibandingkan dengan orientasi terbatas yang ingin dicapai oleh sistem-sistem sekuler, yaitu untuk mencapai keadilan sosial.

Oleh karena itu, untuk mencapai pertumbuhan dan pembangunan secara material dan spiritual tersebut, Islam mempunyai karakteristik dalam pertumbuhannya, yaitu serba meliputi,

\footnotetext{
${ }^{24}$ Karena mempunyai tujuan seperti itulah, sehingga ekonomi Islam tidak hanya bercirikan ketuhanan dan moral saja, tetapi juga bercirikan kemanusiaan. Sementara ide kemanusiaan sendiri adalah berasal dari Allah dan Allahlah yang memuliakan manusia dan menjadikannya sebagai khalifah di muka bumi ini. Lihat: Yusuf Qardhawi, Norma dan Etika Ekonomi Islam, (J akarta: Gema Insani Press, 1995), 57.

${ }^{25}$ Nik Muhammad bin N ik Yusuf Affandi, Islam and Business (Selangor: Pelanduk Publications, 2002), 49-50.

${ }^{26}$ Sehingga sudah seharusnya ekonomi Islam memusatkan perhatiannya pada persoalan-persoalan yang dihadapi oleh negara Muslim dan memberikan usulan-usulan problem solving secara islami dan secara ekonomi dan politik yang memungkinkan untuk diterapkan. Lihat: M. U mer, Chapra The Future of Economics An Islamic Perspective (United Kingdom: The Islamic Foundation, 2000), 373.

${ }^{27}$ A bdul Manan, Teori dan Praktek Ekonomi Islam, terj. M. Nastangin (Yogyakarta: Dana B hakti Prima Yasa, 1997), 379.
} 
berimbang, realistis, berkeadilan, tanggungjawab, mencukupi dan berfokus pada manusia sesuai dengan haknya sebagai khalifah di muka bumi ${ }^{28}$. Karakteristik tersebut menunjukkan bahwa tujuan pertumbuhan dan pembangunan ekonomi dalam Islam adalah adanya kesempatan semua anggota masyarakat-apapun ras, agama dan karakternya- untuk mendapatkan kesejahteraan, sehingga semua orang dapat merasakan nikmat dan karunia Allah Swt.

Dalam al-Q ur'an tegas dikatakan "Supaya harta itu jangan beredar di antara orang-orang kaya saja di antara kamu" 29 ini menunjukkan dengan jelas bahwa kekayaan seharusnya tidak menciptakan lingkaran antar orang kaya saja, tetapi kekayaan tersebut juga memberikan kontribusi kepada kesejahteraan masyarakat secara keseluruhan. Secara mikro bisa diungkapkan bahwa apapun yang diproduksi, pertama-tama harus dibagi diantara faktor-faktor produksi yang ada, dan apapun yang tersisa setelah semua pengurangan maka itulah net profit (keuntungan bersih) yang menjadi milik pengusaha ${ }^{30}$. Secara makro, tentunya negara harus benar-benar memperhatikan tentang distribusi pendapatan, jangan sampai ada diskriminasi antara usaha yang berskala besar dengan usaha yang berskala kecil.

\section{Penutup}

Dalam Islam, tidak ada satupun ajaran yang menganjurkan umatnya untuk menjadi pengemis, pemalas dan miskin. J ustru Islam mengajarkan untuk bisa membayar zakat, bukan menerima zakat; Islam mengajarkan umatnya untuk bisa memberi, bukan meminta. Ini menunjukkan Islam mengajarkan umatnya berdaya di bidang ekonomi, karena untuk bisa membayar zakat, berinfak, dan bersadaqah seseorang harus berdaya di bidang ekonomi. Selain itu, Islam mengajarkan bahwa manusia adalah khalifah Allah di muka bumi yang diberi amanah untuk mengelolanya, sehingga bisa memberikan manfaat pada umat manusia. Kekayaan tidak dapat diperoleh hanya dengan berdiam diri di rumah, atau hanya dengan berdoa saja, tetapi harus dengan usaha yang keras, harus aktif dan kreatif, bahkan perlu juga adanya inovatif. Bisa jadi karena dorongan berusaha itulah, Allah dalam surat al-J umu'ah ayat 10 menggunakan kata perintah "bertebaranlah" dalam rangka mencari karunia Allah.

Oleh karena itu, Islam mewajibkan umatnya untuk memenuhi kebutuhan hidupnya dengan cara bekerja keras untuk mencapai kesejahteraan ekonomi, mereka juga diperintahkan untuk memilih mata pencaharian sesuai dengan bakat dan kecenderungannya, tetapi Islam memberikan aturan-aturan agar orang yang berusaha berdaya di bidang ekonomi tersebut tidak bertentangan dengan prinsip-prinsip ekonomi Islam, yang meliputi; berimbang, realistis, berkeadilan, tanggungjawab, mencukupi dan berfokus pada manusia sesuai dengan haknya sebagai khalifah di muka bumi. Prinsip-prinsip tersebut menunjukkan bahwa keberdayaan ekonomi dalam Islam adalah adanya kesempatan semua anggota masyarakat untuk mendapatkan kesejahteraan, sehingga semua orang dapat merasakan nikmat dan karunia Allah Swt.

\footnotetext{
${ }^{28}$ Abdullah Abdul Husain, Ekonomi Islam; Prinsip, Dasar dan Tujuan (Yogyakarta: Magistra Insania Press, 2004), 299.

${ }^{29}$ al-Qur'an, 59 (al-Hashr) : 7.

${ }^{30}$ Muhammad Muslehudin, Wacana B aru Manajemen dan Ekonomi Islam (Yogjakarta: IRCiSoD, 2004), 144.
} 
Sebagai catatan akhir, kalau ajaran Islam sangat menganjurkan umatnya untuk berdaya di bidang ekonomi, bahkan dari sekian banyak ayat al-Q ur'an tidak ada satupun yang mengajarkan umatnya untuk menjadi pengemis, tetapi mengapa umatnya sendiri banyak yang tidak berdaya di bidang ekonomi?, kalaupun diadakan survey kepada para pengemis, maka rata-rata mereka adalah beragama Islam. Inilah barangkali yang perlu menjadi bahan pemikiran kita semua.

Wa Allah a'lam bi al-sałwab.

\section{Daftar Rujukan}

Abdullah, Taufik. Agama, Etos Kerja dan Perkembangan Ekonomi. J akarta: LP3ES, 1979.

Ahmad, Mustaq. Business Ethics in Islam. Pakistan: The International Institute of Islamic Thought, 1999.

Chapra, M. Umer. The Future of Economics An Islamic Perspective. United Kingdom: The Islamic Foundation, 2000.

Djohohadikusumo, Sumitro. Perkembangan Pemikiran Ekonomi; Dasar Teori Ekonomi Pertumbuhan dan Ekonomi Pembangunan. J akarta: LP3ES, 1994.

Husain, Abdullah Abdul. Ekonomi Islam; Prinsip, Dasar dan Tujuan. Yogyakarta: Magistra Insania Press, 2004.

al-J awziyah, Ibn al-Q ayyim. A'lam al-M uwaqi' in, J uz III. Beirut: Dar al-Kutub al-'Ilmiyah,1993. Manan, M. Abdul. Islamic Economic, Theory and Practice. New Delhi: Idarat-i Delhi, 1980.

- - - - . Teori dan Praktek Ekonomi Islam, terj. M. Nastangin. Yogyakarta: Dana Bhakti Prima Yasa, 1997.

Muslehudin, Muhammad. Wacana Baru Manajemen dan Ekonomi Islam. Yogjakarta: IRCiSoD, 2004.

Mubyarto. Membangun Sistem Ekonomi. Yogyakarta : BPFE, 2000.

Mulkhan, Abdul Munir. "Pemberdayaan Budaya Ekonomi Domestik", dalam Hadi, Kumala (ed). Agenda Aksi Liberalisasi Ekonomi dan Politik di Indonesia. Yogyakarta : PT. Tiara Wacana, 1997.

Naqvi, Syed Nawab Haider. Islam; Economic and Society. London and New York: Kegan Paul International, 1994.

Nik Yusuf Affandi, Nik Muhammad bin. Islam And Business. Selangor: Pelanduk Publications, 2002.

a-Nawawi. S \{ahilh M uslim bi Sharh /mam al-Nawawi,>VIII. Beirut: Dasal-Fikr, 1981.

Qardhawi, Yusuf. Norma dan Etika Ekonomi Islam. J akarta: G ema Insani Press, 1995.

Rahardjo, M. Dawam. Perekonomian Indonesia; Pertumbuhan dan Krisis. J akarta : LP3ES, 1997.

Shihab, Alwi. Islam Inklusif ;M enuju Sikap Terbuka dalam Beragama. Bandung: Mizan, 1997. Sukirno. Pengatar Teori Mikro Ekonomi. J akarta: Rajawali Pers, 1994.

Suparlan, Parsudi. Kemiskinan di Perkotaan; Bacaan untuk Antropologi Perkotaan. Jakarta: Yayasan Obor Indonesia, 1995.

Wilopo. "Pemerataan Bukan Rata-Rata", dalam Sri Edi Swasono (ed). Sistem Ekonomi Dan Demokrasi Ekonomi. J akarta: UI-Press, 1987. 